\title{
Reactions of Accessions in the Annual Medicago Core Germ Plasm Collection to Erysiphe pisi
}

\author{
J. R. Yaege and D. L. Stuteville, Department of Plant Pathology, Throckmorton Plant Sciences Center, Kansas \\ State University, Manhattan 66506-5502
}

\begin{abstract}
Yaege, J. R., and Stuteville, D. L. 2002. Reactions of accessions in the annual Medicago core germ plasm collection to Erysiphe pisi. Plant Dis. 86:312-315.

Reaction to Erysiphe pisi was evaluated in the annual Medicago core germ plasm collection of 199 USDA Plant Introduction accessions from 33 species. Seedlings at the first trifoliolate leaf stage were inoculated with conidia and maintained in growth chambers for 21 days at $20^{\circ} \mathrm{C}, 70$ to $90 \%$ relative humidity, and a 12 -h photoperiod. Beginning 4 days after inoculation, plants with the first sign of powdery mildew were recorded and removed daily. Results for each accession were presented as the percentage of plants mildew-free 21 days after inoculation and also as area under the disease progress curve (AUDPC) values expressed as standardized proportion/days. AUDPC values were useful to account for length of latent period (number of days from inoculation until first sign of mildew). Thirty-two accessions from 14 species included plants mildew-free 21 days after inoculation. Mildew-free plants in those 32 accessions ranged from $100 \%$ in M. heyniana PI 537136 and M. truncatula PI 292436 down to $1 \%$ in six accessions. All plants in 87 accessions, which included all accessions of 11 species, had powdery mildew 4 days after inoculation and thus expressed no resistance. The remaining 80 accessions included slow-mildewing plants with latent periods of 5 to 14 days. This slow-mildewing trait may be a useful source of resistance to E. pisi.
\end{abstract}

Annual species of Medicago, commonly known as medics, self-pollinate, self-seed, host nitrogen-fixing bacteria, and except for M. lupulina L., complete their life cycle in one growing season (14). Medics have long been utilized in areas of Australia (6) and South Africa (13), and more recently they have received increased attention in the United States as cover crops, companion crops, and pasture legumes in crop rotations, particularly in sustainable agriculture systems $(2,20)$.

The medics evolved from perennial Medicago species $(14,16)$, and therefore medics and alfalfa (Medicago sativa L.) share many diseases $(9,17)$. Powdery mildew (21) occurs worldwide on Medicago spp. (1), but reports in the United States have been sparse (9) and only recently have included major alfalfa production areas in the North Central (8) and Northwest (15). In 1999, powdery mildew was first reported on 21 medic species in the United States, in a seed-increase nursery at Riverside, CA (10).

Erysiphe polygoni DC has long been cited as the cause of powdery mildew on a

Corresponding author: D. L. Stuteville

E-mail: dls@plantpath.ksu.edu

This is contribution number 01-306-J from the Kansas Agricultural Experiment Station.

Accepted for publication 27 November 2001.

Publication no. D-2002-0123-03R

(C) 2002 The American Phytopathological Society wide range of plants, including Medicago species, in the United States (9). Current widely used keys $(3,4)$ restrict $E$. polygoni to the Polygonaceae and cite Erysiphe pisi DC. ex St.-Am. as the cause of powdery mildew of Medicago species. The teleomorph of E. pisi has not been reported on Medicago species in the United States, and identification has been based on the morphology of the Oidium conidial state and host range (3).

The recent reports of $E$ pisi on medics (10) and alfalfa $(8,15)$ indicate a need for more information on resistance within Medicago. The annual Medicago core collection, comprised of 211 accessions from 36 species, was developed to represent the genetic variability in the U.S. National Plant Germplasm System medic collection of over 3,000 accessions (7). Our objective was to evaluate the reaction of these core medic accessions to $E$. pisi from alfalfa.

\section{MATERIALS AND METHODS}

Seed source. Seed of 199 Plant Introduction (PI) accessions of the annual Medicago core collection (7) were obtained from the USDA Western Regional Plant Introduction Station, 59 Johnson Hall, Pullman, WA.

Inoculum. The inoculum source was a monoconidial isolate of $E$. pisi recovered from an alfalfa plant with powdery mildew collected near Arlington, WI, in 1997. That isolate was the basis of the first report of powdery mildew in alfalfa fields in Wisconsin (8) and has since been designated isolate PM1. Conidia were used as inocu- lum and were produced on potted plants of Medicago lupulina PI 215245 in a growth chamber at $20^{\circ} \mathrm{C}$ and a 12 -h photoperiod. To ensure that mostly young conidia were used as inoculum for experiments, conidia were shaken from the inoculum source plants 2 days prior to the inoculations. To maintain an inoculum supply, at approximately 2-week intervals, pots of 1-monthold plants were inoculated by shaking conidia onto them from mildewed plants.

Test procedures. Each week, approximately 24 seeds from each of 19 accessions and the susceptible control, Medicago lupulina PI 215245, were planted in 8 $\mathrm{cm}^{2}$ pots of Jiffy-Mix Plus (Jiffy Products of America Inc., Batavia, IL) potting mix. The pots were placed in a growth chamber at $20^{\circ} \mathrm{C}$ and with continuous cool-white fluorescent lighting. Those conditions favored the production of sturdy plants with relatively large unifoliolate leaves that were the primary inoculation target. The plants were inoculated 2 weeks after seeding, when most were at the early first trifoliolate leaf stage. A pot from each of 19 accessions and M. lupulina PI 215245, and an open petri dish of $2 \%$ water agar, were placed in the bottom of a metal trash can, $55 \mathrm{~cm}$ in diameter $\times 68 \mathrm{~cm}$ tall, which served as an inoculation chamber. Pots of mildewed plants of M. lupulina PI 215245 were inverted above the can, and conidia were brushed off by hand until a minimum of 24 conidia per $1 \mathrm{~mm}^{2}$ had fallen onto the plate of water agar. To monitor spore concentration, a screen with $1 \mathrm{~mm}^{2}$ cells was placed on the agar surface and the mean number of conidia in five randomly selected cells was counted with a dissecting microscope. The inoculated plants and the petri dish were then placed in a growth chamber at $20^{\circ} \mathrm{C}$, a $12-\mathrm{h}$ photoperiod of cool-white fluorescent lighting, and 70 to $90 \%$ relative humidity. One day later the percentage of germinated conidia in five randomly selected $1 \mathrm{~mm}^{2}$ cells was determined. Germination of conidia was 60 to $70 \%$.

Beginning on the fourth day after inoculation, plants were observed daily, and those with macroscopic signs of powdery mildew were recorded and removed. On day 21 after inoculation, the number of plants remaining per entry was recorded and the test was terminated. This procedure was continued until the 199 accessions of the first replication were evaluated (11 weeks), and then was repeated until six independent replications were completed (total of 66 weeks). 
Table 1. Reactions in the annual Medicago core collection Plant Introduction (PI) accessions to isolate PM1 of Erysiphe pisi

\begin{tabular}{|c|c|c|c|c|c|c|c|c|c|c|c|}
\hline Species & PI & $\% \mathbf{R}^{\mathrm{a}}$ & AUDPC $^{b}$ & Species & PI & $\% \mathbf{R}^{\mathbf{a}}$ & $\mathbf{A U D P C}^{\mathbf{b}}$ & Species & PI & $\% \mathbf{R}^{\mathbf{a}}$ & $\mathbf{A U D P C}^{\mathbf{b}}$ \\
\hline \multirow[t]{2}{*}{ M. arabica } & 495200 & 0 & 0.73 & & 215245 & 0 & 1.52 & M. praecox & 495429 & 0 & 1.59 \\
\hline & 495212 & 0 & 0.57 & & 223872 & 0 & 1.26 & & 495434 & 0 & 1.59 \\
\hline \multirow[t]{7}{*}{ M. blancheana } & 495215 & 46 & 0.59 & & 227452 & 0 & 1.01 & M. radiata & 340800 & 0 & 0.45 \\
\hline & 495216 & 0 & 0.99 & & 234821 & 1 & 0.92 & & 459142 & 1 & 0.86 \\
\hline & 495223 & 0 & 1.54 & & 251834 & 29 & 0.90 & & 459145 & 8 & 0.85 \\
\hline & 495227 & 0 & 0.55 & & 269926 & 0 & 1.30 & & 459146 & 13 & 0.66 \\
\hline & 505415 & 4 & 0.77 & & 290723 & 0 & 1.55 & M. rigidula & 230350 & 0 & 1.54 \\
\hline & 505416 & 1 & 0.65 & & 304527 & 0 & 1.28 & & 233250 & 0 & 1.52 \\
\hline & 537130 & 0 & 1.38 & & 308059 & 0 & 1.52 & & 319048 & 0 & 1.55 \\
\hline \multirow{6}{*}{ M. ciliaris } & 368928 & 0 & 1.59 & & 314538 & 0 & 1.28 & & 495517 & 0 & 1.56 \\
\hline & 442645 & 70 & 0.23 & & 319026 & 0 & 0.93 & & 534236 & 0 & 1.57 \\
\hline & 498731 & 0 & 1.53 & & 452459 & 0 & 1.44 & & 534250 & 0 & 1.58 \\
\hline & 498750 & 0 & 1.59 & & 532942 & 0 & 1.19 & M. rotata & 292430 & 0 & 0.97 \\
\hline & 498784 & 0 & 1.56 & & 566869 & 0 & 1.49 & & 495576 & 0 & 0.99 \\
\hline & 498785 & 0 & 1.55 & M. minima & 227032 & 0 & 1.61 & & 495577 & 3 & 0.77 \\
\hline \multirow[t]{3}{*}{ M. constricta } & 495240 & 0 & 1.54 & & 499072 & 0 & 1.58 & & 495583 & 3 & 0.84 \\
\hline & 534177 & 0 & 1.53 & & 499080 & 0 & 1.54 & & 495586 & 0 & 1.06 \\
\hline & 534182 & 0 & 1.53 & M. murex & 308062 & 0 & 1.59 & & 537236 & 0 & 1.07 \\
\hline \multirow[t]{2}{*}{ M. coronata } & 498790 & 9 & 0.97 & & 495350 & 0 & 1.53 & M. rugosa & 308061 & 0 & 1.30 \\
\hline & 498805 & 1 & 1.02 & & 495379 & 0 & 1.51 & & 368962 & 0 & 1.58 \\
\hline \multirow{4}{*}{ M. disciformis } & 487317 & 97 & 0.10 & & 516720 & 0 & 1.54 & & 442893 & 0 & 1.40 \\
\hline & 487321 & 60 & 0.68 & & 534231 & 0 & 1.52 & & 487363 & 0 & 1.59 \\
\hline & 487322 & 99 & 0.06 & & 566894 & 0 & 1.52 & & 487374 & 0 & 1.51 \\
\hline & 487333 & 0 & 1.51 & M. muricoleptis & 495401 & 5 & 0.61 & & 487377 & 0 & 1.40 \\
\hline \multirow[t]{4}{*}{ M. doliata } & 495278 & 0 & 1.60 & M. noeana & 495407 & 0 & 1.53 & & 487379 & 0 & 1.26 \\
\hline & 505420 & 0 & 1.52 & & 495414 & 97 & 0.05 & & 487382 & 0 & 1.38 \\
\hline & 534202 & 0 & 1.57 & M. orbicularis & 210425 & 0 & 1.56 & & 487386 & 0 & 1.55 \\
\hline & 534211 & 0 & 1.57 & & 251474 & 0 & 1.04 & & 535534 & 0 & 1.55 \\
\hline \multirow[t]{3}{*}{ M. granadensis } & 498812 & 0 & 1.40 & & 283645 & 0 & 1.53 & & 535537 & 0 & 1.57 \\
\hline & 498813 & 0 & 1.59 & & 292421 & 0 & 1.27 & M. sauvagei & 499152 & 0 & 1.54 \\
\hline & 498817 & 0 & 1.55 & & 505425 & 0 & 1.49 & & 499153 & 0 & 1.54 \\
\hline M. heyniana & 537136 & 100 & 0.03 & & 566870 & 0 & 1.58 & M. scutellata & 161415 & 0 & 1.58 \\
\hline \multirow[t]{5}{*}{ M. intertexta } & 498824 & 0 & 1.59 & & 566871 & 0 & 1.53 & & 197806 & 0 & 1.58 \\
\hline & 516649 & 0 & 1.54 & & 566872 & 0 & 1.58 & & 197817 & 0 & 1.54 \\
\hline & 516650 & 0 & 1.57 & M. polymorpha & 186329 & 0 & 1.58 & & 197821 & 0 & 1.61 \\
\hline & 535606 & 0 & 1.57 & & 197340 & 0 & 1.61 & & 292432 & 0 & 1.49 \\
\hline & 535607 & 0 & 1.52 & & 197530 & 0 & 1.60 & & 487389 & 0 & 1.57 \\
\hline M. italica & 384640 & 1 & 1.19 & & 206695 & 0 & 1.56 & & 487392 & 0 & 1.47 \\
\hline & 385014 & 4 & 1.20 & & 226648 & 0 & 1.54 & & 487393 & 0 & 1.56 \\
\hline & 459188 & 0 & 1.52 & & 244312 & 0 & 1.61 & & 487394 & 0 & 1.55 \\
\hline & 566864 & 54 & 0.70 & & 250782 & 0 & 1.56 & & 487396 & 0 & 1.57 \\
\hline & 566865 & 0 & 1.58 & & 253448 & 0 & 1.49 & & 487403 & 0 & 1.59 \\
\hline & 566866 & 12 & 0.89 & & 283657 & 0 & 1.58 & & 487409 & 0 & 1.56 \\
\hline & 566867 & 5 & 1.32 & & 286534 & 0 & 1.36 & & 487411 & 0 & 1.55 \\
\hline & 566868 & 78 & 0.26 & & 292427 & 0 & 1.59 & & 516907 & 0 & 1.53 \\
\hline M. laciniata & 498839 & 0 & 1.56 & & 302926 & 0 & 1.37 & & 517255 & 0 & 1.53 \\
\hline & 498841 & 0 & 1.53 & & 308055 & 0 & 1.53 & & 535643 & 0 & 1.18 \\
\hline & 498842 & 0 & 1.40 & & 319036 & 0 & 1.59 & & 535644 & 0 & 1.35 \\
\hline & 498853 & 0 & 1.52 & & 368949 & 0 & 1.59 & & 535645 & 0 & 1.54 \\
\hline & 498864 & 0 & 1.57 & & 385017 & 1 & 1.12 & M. soleirolii & 537242 & 0 & 1.56 \\
\hline & 498890 & 0 & 1.45 & & 404795 & 0 & 1.58 & & 537243 & 0 & 1.55 \\
\hline & 498902 & 0 & 1.22 & & 459130 & 0 & 1.58 & M. tenoreana & 499161 & 0 & 1.24 \\
\hline & 498916 & 0 & 1.55 & & 478531 & 0 & 1.55 & M. truncatula & 292436 & 100 & 0.02 \\
\hline & 498918 & 0 & 1.54 & & 493292 & 0 & 1.55 & & 384648 & 0 & 1.58 \\
\hline & 535738 & 0 & 1.35 & & 493293 & 0 & 1.57 & & 566886 & 0 & 1.30 \\
\hline M. lanigera & 498930 & 0 & 1.22 & & 566873 & 0 & 1.58 & & 566887 & 67 & 0.47 \\
\hline M. lesinsii & 534233 & 0 & 1.57 & & 566874 & 0 & 1.58 & & 566888 & 28 & 0.71 \\
\hline & 537259 & 0 & 1.58 & & 566875 & 0 & 1.54 & & 566889 & 0 & 1.51 \\
\hline M. littoralis & 385006 & 0 & 1.58 & & 566876 & 0 & 1.57 & & 566890 & 11 & 1.16 \\
\hline & 517206 & 0 & 1.53 & & 566877 & 0 & 1.52 & & 566891 & 0 & 1.18 \\
\hline & 537168 & 0 & 1.56 & & 566879 & 0 & 1.55 & & 566892 & 85 & 0.26 \\
\hline & 537171 & 0 & 0.93 & & 566880 & 0 & 1.57 & M. turbinata & 441943 & 0 & 1.58 \\
\hline & 537201 & 10 & 0.71 & & 566881 & 0 & 1.51 & & 535555 & 0 & 1.57 \\
\hline & 537207 & 0 & 1.38 & & 566882 & 0 & 1.53 & & 566893 & 0 & 1.52 \\
\hline & 537222 & 0 & 1.58 & & 566883 & 0 & 1.57 & & 566895 & 0 & 1.52 \\
\hline M. lupulina & 189128 & 0 & 1.60 & & 566884 & 0 & 1.57 & & & & \\
\hline & 202038 & 0 & 0.93 & & 566885 & 0 & 1.57 & $\operatorname{LSD}(P \leq 0.05)$ & & & 0.16 \\
\hline
\end{tabular}

a Mean percentage of plants resistant (without powdery mildew) 21 days after inoculation.

b Mean area under the disease progress curve (AUDPC) of 6 replications (standardized proportion/days transformed by the arcsine square root). The AUDPC was based on daily disease incidence for 21 days following inoculation. 
Data analysis. Statistical analysis included six replications in a randomized incomplete block design with blocking on each inoculation date. The area under the disease progress curve (AUDPC) was calculated for each PI accession and was expressed as standardized proportion/days (5). The AUDPC scores were transformed by the arcsine square root to correct for unequal variances and were analyzed with an SAS MIXED procedure followed by an SAS LSMEANS procedure. Mean comparisons were made using a least significant difference test at the 0.05 level of probability.

\section{RESULTS}

Thirty-two accessions, representing 14 species, included plants mildew-free 21 days after inoculation. The percentage of mildew-free plants ranged from $100 \%$ in M. heyniana PI 537136 and M. truncatula PI 292436 to $1 \%$ in six accessions (Table 1). The other 167 accessions had no plants that were mildew-free at 21 days. All plants in 87 of those accessions had powdery mildew by 4 days after inoculation. Those included all accessions of $M$. constricta, M. doliata, M. intertexta, M. lesinsii, M. minima, M. murex, M. praecox, $M$. rigidula, $M$. sauvagei, $M$. soleirolii, and $M$. turbinata. The remaining 80 accessions included plants that expressed latent periods greater than 4 days but less than 21 days.

AUDPC values reflected the accumulative daily disease incidence for 21 days and thus provided a means to evaluate latent periods. Accessions in Table 1 with AUDPC values greater than 1.50 included no plants with latent periods greater than 4 days. AUDPC values were particularly useful in identifying and evaluating the 80 accessions with all plants expressing latent periods greater than 4 days but less than 21days, and thus listed with $0 \%$ mildewfree plants in Table 1. The lowest AUDPC value among those was 0.45 for $M$. radiata PI 340800 (Table 1) in which the latent period for all plants was 7 to 11 days. The second lowest AUDPC value among the 80 accessions (0.55) was for M. blancheana PI 495227 with latent periods of 6 to 9 days. Third (0.57) was $M$. arabica PI 495212 with latent periods of 6 to13 days. The rest of those 80 accessions included plants with latent periods of 4 to 12 days.

A few accessions with mildew-free plants at 21 days also included no plants expressing a short latent period. The shortest latent periods recorded for plants in those accessions were 9 days for $M$. italica PI 566868; 8 days for $M$. blancheana PI 495215, M. ciliaris PI 442645, M. disciformis PI 487317 and PI 487322, M. muricoleptis PI 495401, and $M$. radiata PI 459146; and 7 days for $M$. truncatula PI 566892.

Mildew often appeared simultaneously on the cotyledons and the unifoliolate leaf of plants. In some accessions, however, a portion of plants expressed mildew first on the cotyledons. Latent periods on those plants were at least 6 days and usually 8 to 10 days. This trait was particularly evident on M. blancheana PI 495215, PI 495227, PI 505415, and PI 505416; $M$. coronata PI 498790; M. italica PI 566864, PI 566866, and PI 566868; M. lupulina PI 251834; $M$. muricoleptis PI 495401; M. polymorpha PI 385017; $M$. radiata PI 459142 and PI 459145; M. rotata PI 537236; M. rugosa PI 487379; and M. truncatula PI 566888, PI 566890, PI 566891, and PI 566892.

All plants of $M$. heyniana PI 537136 were free of symptoms. Small necrotic hypersensitive reactions were common on the unifoliolate leaf of many plants where fruiting of E. pisi did not occur, particularly on plants of $M$. truncatula and $M$. italica. The necrotic reaction was most severe and killed unifoliolate leaves on some plants of M. littoralis PI 537201, although conidium production occurred on their cotyledons.

Most plants of $M$. disciformis PI 487321 were either very susceptible or very resistant; $35 \%$ had mildew 4 days after inoculation and $60 \%$ were symptomless 21 days after inoculation (Table 1).

\section{DISCUSSION}

The wide range of plant reactions to $E$. pisi that we observed within and among accessions suggested that the medics harbor diverse sources of resistance to the fungus. A diversity of reactions also was reported during a powdery mildew epidemic in South Africa in which two of 13 accessions of $M$. truncatula were rated resistant, nine moderately resistant, and two susceptible (13). We also noted a wide range in reactions among the nine $M$. truncatula accessions that we evaluated (Table 1). In South Africa, two of six entries of $M$. polymorpha were resistant and four were moderately resistant, whereas only one of the 33 PIs of $M$. polymorpha expressed any resistance in our study (Table 1 ). The single entry of $M$. turbinata in their study was rated resistant, whereas we found no resistance in the four accessions evaluated (Table 1). Although a diversity of reactions was observed, we had no entries in common with those evaluated in the South African study and thus have no basis for comparing pathogenicity of the fungal isolates.

The 11 medic species with no plants expressing any resistance in our tests were represented by only 39 accessions. Perhaps additional accessions would have identified resistance in more of those species.

Field data of Graves et al. (10) revealed that 19 core medic accessions were included in seed increases at Riverside, CA, and powdery mildew was found on plants of five of them. Those were $M$. doliata PI 534202, M. intertexta PI 516650, M. murex PI 495350, $M$. rigidula PI 495517, and $M$. scutellata PI 487393. In our evaluations (Table 1), those five accessions expressed no resistance. Of the 14 core accessions without mildew at Riverside, only $M$. noeana PI 495414 had plants that were free of mildew in our tests. That was likely due to greater mildew severity under our controlled conditions.

The host range for E. pisi recovered from alfalfa from Idaho and Oregon (15) does not conflict with the known host ranges of $E$. pisi isolates recovered from alfalfa from Wisconsin (8) or medics from California (10). All three isolates infected pea cv. Early Perfection.

The slow development of E. pisi (slowmildewing) that occurred in several medic accessions also occurs in garden pea $(11,12)$. Major gene resistance to $E$. pisi in pea is short-lived due to frequent changes in pathogen virulence (11). Slowmildewing in pea is expressed in slower mycelial growth, and thus longer latent periods, smaller lesions, and fewer conidia per lesion (12). Slow-mildewing in pea appears to be a quantitatively inherited trait and therefore a more stable source of resistance (11). Slow-mildewing of wheat cv. Knox past the seedling stage by Erysiphe graminis f. sp. tritici was attributed to race nonspecific resistance that behaved genetically as a quantitative trait (18). The AUDPC procedures that we used were developed to evaluate slow-mildewing of wheat (19) and also were used successfully to evaluate slow mildewing of pea by $E$. pisi (11).

Latent periods for pea entries were from 100.2 to $122.4 \mathrm{~h}$ (4.2 to 5.1 days) (12). Thus, the latent period for the slowest mildewing entry was approximately 1 day longer than for the fastest mildewing entry. Latent periods of 8 to 10 days were common among medic plants under our test conditions. If these long latent periods are expressed under field conditions, and are quantitatively inherited, they should provide a stable source of resistance to $E$. pisi in several medic species.

\section{ACKNOWLEDGMENTS}

We thank the personnel at the USDA Western Regional Plant Introduction Station for providing seed of the core collection.

\section{LITERATURE CITED}

1. Amano (Hirata), K. 1986. Host range and geographical distribution of the powdery mildew fungi. Japan Scientific Societies Press, Tokyo.

2. Bauchan, G., and Sheaffer, C. 1994. Annual medics and their use in sustainable agriculture systems. Pages 3-5 in: Rep. N. Am. Alfalfa Improv. Conf., 34th, Univ. of Guelph, Guelph, Ont. Canada.

3. Boesewinkel, H. J.1980. The morphology of the imperfect states of powdery mildews (Erysiphaceae) Bot. Rev. 46:167-224.

4. Braun, U. 1987. A monograph of the Erysiphales (powdery mildews). Nova Hedwigia 89:1-664.

5. Campbell, C. L., and Madden, L. V. 1990. Temporal analysis of epidemics 1: Description and comparison of disease progress 
curves. Pages 161-202 in: Introduction to Plant Disease Epidemiology. John Wiley \& Sons, New York.

6. Crawford, E. J., Lake, A. W. H., and Boyce, K. G. 1989. Breeding annual Medicago species for semiarid conditions in southern Australia. Adv. Agron. 42:399-437.

7. Diwan, N., Bauchan, G. R., and McIntosh, M. S. 1994. A core collection for the United States annual Medicago germplasm collection. Crop Sci. 34:279-285.

8. Edmunds, J. I., Miller, D. J., and Stuteville, D. L. 1998. Powdery mildew caused by an Oidium sp. in alfalfa in Wisconsin. Plant Dis. 82:832.

9. Farr, D. F., Bills, G. F., Chamuris, G. P., and Rossman, A. Y. 1989. Fungi on Plants and Plant Products in the United States. American Phytopathological Society, St. Paul, MN.

10. Graves, W. L., Stuteville, D. L., Johnson, R. C., and Greene, S. L. 1999. Powdery mildew caused by an Oidium sp. on twenty-one annual Medicago spp. in California. Plant Dis. 83:1176.

11. Kapoor, A. S., and Kumar, J. 1996. Evaluation of slow mildewing resistance in pea. Him. J. Agric. Res. 22:31-35.

12. Krishna, A., and Mishra, S. P. 1989. Mechanism of slow mildewing in pea. Indian Phytopathol. 42:103-107.

13. Lamprecht, S. C., and Knox-Davies, P. S. 1984. Preliminary survey of foliage diseases of annual Medicago spp. in South Africa. Phytophylactica 16:177-183.

14. Lesins, K., and Lesins, I. 1979. Genus Medicago (Leguminosae). A taxogenetic study. Junk, The Hague, Netherlands.

15. Mohan, S. K., Bijman, V. P., and Miller, D. R. 2001. Powdery mildew caused by Erysiphe pisi on alfalfa in Idaho and Oregon. Plant Dis. $85: 678$

16. Quiros, C. F., and Bauchan, G. R. 1988. The genus Medicago and the origin of the Medi- cago sativa complex. Pages 93-124 in: Alfalfa and Alfalfa improvement. A. A. Hanson, ed. American Society of Agronomy, Madison, WI.

17. Renfro, B. L., and Sprague, E. W. 1959. Reaction of Medicago species to eight alfalfa pathogens. Agron. J. 51:481-483.

18. Shaner, G. 1973. Evaluation of slowmildewing resistance of Knox wheat in the field. Phytopathology 63:867-872.

19. Shaner, G., and Finney, R. E. 1977. The effect of nitrogen fertilization on the expression of slow mildewing resistance in Knox wheat Phytopathology 67:1051-1056.

20. Sheaffer, C. C., and Barnes, D. K. 1994. An nual medics in Minnesota agriculture. Page 7 in: Rep. N. Am. Alfalfa Improv. Conf., 34th, Univ. of Guelph, Guelph, Ont., Canada.

21. Yarwood, C. E. 1978. History and taxonomy of powdery mildews. Pages 1-37 in: The Powdery Mildews. D. M. Spencer, ed. Academic Press, New York. 